\title{
Biochemical analysis of ginger-infused water with a combination of lemon and mint leaves
}

\author{
Rika Sepriani ${ }^{1, *}$ and Deswandi ${ }^{1}$ \\ ${ }^{1}$ Department of Physical Education, Faculty of Sport Science, Universitas Negeri Padang, Indonesia, \\ Gedung F, Jl. Prof. Dr. Hamka, Padang 25131, West Sumatera, Indonesia
}

\begin{abstract}
Infused water is a beverage made possible by the incorporation of fruit or herbs into the water. The purpose of this study is to determine the antioxidant activity, vitamin $\mathrm{C}$ content, and $\mathrm{pH}$ value of ginger-infused water with lemon and mint leaves. This study used three ginger varieties: red ginger, small (emprit) ginger, and elephant ginger, with immersion times of 6,9 , and 12 hours. The DPPH method was used to determine antioxidant activity, and UV-Vis spectrometry was used to determine vitamin $\mathrm{C}$ levels. A pH meter was used to determine the degree of acidity $(\mathrm{pH})$. According to the study's findings, red ginger had the highest antioxidant activity at 12 hours of immersion by 89 percent. At $72.44 \mathrm{ppm}$ immersion for 12 hours, the highest levels of vitamin $\mathrm{C}$ were found in infused water with small (emprit) ginger and a combination of lemon and mint leaves. Red ginger with a combination of lemon and mint leaves had the lowest $\mathrm{pH}$, with a value of 3.48 after 12 hours of immersion. Research shows the biochemical content of infused water that is often used in society, especially ginger infused water combined with lemon and mint leaves.
\end{abstract}

\section{Introduction}

Infused water is an alternative to drinking water to maintain fluid balance after exercise while also allowing spices or fruit. Infused water is drinking water that has been infused with pieces of fruit, vegetables, or spices to allow the juices to come out and provide flavor and various health benefits to those who drink it [1]. The exact origin of the development of infused water is unknown. However, based on a blogger's experience from Oregon, United States of America, it has grown in popularity since 2012 [1]. Infused water is created by immersing pieces of fruit, vegetables, or spices in drinking water and storing them for a while.

Infused water is a type of drink that results from the diffusion of fruit or herbs into the water. The compound movement from a high concentration to a low concentration without passing through a semi-permeable membrane is called diffusion. In infused water drinks, water-soluble vitamins and minerals will be extracted directly. The primary nutritional content of infused water is vitamins, minerals, and fiber. Infused water, also known as spa water, is water mixed with fruit and then allowed to stand or ferment for several hours until

\footnotetext{
*Corresponding author: rikasepriani@fik.unp.ac.id
} 
the juices are beneficial to the body's health [2]. These vitamins and minerals are required for physical activity because they act as antioxidants, increasing oxygen uptake in the blood's oxidation process to produce energy.

Infused water is made from materials that are commonly found in the home. In the production of infused water, two types of ingredients are used: spices and fruit and additional ingredients. Because the ingredients and elements differ, variations in ingredients affect the quality of infused water. During soaking and standing, the elements in the material will be extracted, particularly compounds that are soluble in water. In this study, infused water will be made with a blend of spices and fruit. Ginger in various forms, lemon, and mint leaves are among the ingredients used. With a diverse range of drinks, infused herbs are frequently used in traditional medicine worldwide [3]. Herbs that are frequently used include ginger, lemon, and mint leaves.

Ginger is classified into three types based on the rhizome's size, shape, and color: red ginger, emprit ginger, and elephant ginger. Red ginger is the smallest, red to orange color, with a strong aroma and coarse fibers. Small (emprit) ginger is medium-sized ginger that is white or yellow, slightly flattened, fibrous, and not too sharp. While elephant ginger has the largest rhizome size, it is yellow or light yellow, has little fiber, is soft, and has a mild aroma. Ginger has 8.6 percent protein, 6.4 percent fat, 6.9 percent fiber, 66.5 percent carbohydrates, 5.7 percent ash, 0.1 percent calcium, 0.15 percent phosphorus, 0.03 percent sodium, potassium) 1.4 percent, vitamin A $175 \mathrm{IU} / 100 \mathrm{gr}$, vitamin B $0.05 \mathrm{mg} / 100 \mathrm{gr}$, vitamin B2 $0.13 \mathrm{mg} / 100 \mathrm{gr}$, vitamin C $12 \mathrm{mg} / 100 \mathrm{gr}$, niacin $1.9 \mathrm{mg} / 100 \mathrm{gr}$, calories $380 \mathrm{cal} / 100 \mathrm{gr}$ [4]. Ginger contains antioxidants in the form of gingerols, shogaol, and gingerone, in addition to Vitamin E. Lemon is an excellent source of phytochemicals, including flavonoids, citric acid, vitamins, and minerals (Tamer, Yekeler, opur, ncedayi, \& Suna, 2017). Lemons have a high vitamin C content, with $53 \mathrm{mg}$ per 100 grams of seedless raw material and $50 \mathrm{mg}$ per 100 grams of edible weight (Nutrition, 2009; USDA, 2016).

According to Wahyuningsih et al. [8], the antioxidant activity of red ginger-infused water is 88.26 percent RSA DPPH and 92.83 percent FRAP; vitamin C $158.69 \mathrm{mg} / 100 \mathrm{~g}$; acidity degree 2.90 ; total phenol $40.22 \mathrm{mg}$ gallic acid/100 ml; total sugar content 3.78 percent; sour taste $(2,53)$; not sweet taste $(1,46)$; slightly spicy taste $(1.86)$; smell a little like (1.93); and overall liking was slightly like $(1,53)$. Meanwhile, according to Harifah et al. [9], the antioxidant activity of lemon and grape infused water was 68.42 percent RSA DPPH; vitamin C content was $172.48 \mathrm{mg} / 100 \mathrm{~g}$; total sugar content was 52.90 percent; $\mathrm{pH}$ was 5.50; total phenol content was $36.95 \mathrm{mg} / 100 \mathrm{ml}$; non-sour taste $(1,26)$; slightly bitter taste (1.60); comfort smell $(2,26)$; and overall liking was slightly like (1.93). The purpose of this study is to determine the antioxidant activity, vitamin $\mathrm{C}$ levels, and degree of acidity $(\mathrm{pH})$ of ginger water infusion with a combination of lemon and mint leaves with soaking times of 6,9 , and 12 hours.

\section{Methodology}

The measurement of antioxidant activity, vitamin $\mathrm{C}$ levels, and the $\mathrm{pH}$ value of gingerinfused water with a combination of lemon and mint leaves was carried out in stages, namely: tool and material preparation, infused water production, measurement of antioxidant activity, vitamin $\mathrm{C}$ levels, and $\mathrm{pH}$ values, and data analysis.

The tools used in this study is an UV-Vis spectrophotometry, $\mathrm{pH}$ meter, measuring flask, digital scale, goiter pipette, oven, filter paper, funnel, beaker and aluminum foil. The Ingredients used are red ginger, small (emprit) ginger, elephant ginger, lemon, mint leaves, DPPH powders, ascorbic acid standard powder and aquadest.

The ginger used in this study is red, small (emprit), and elephant ginger. The skin of ginger is scraped off and washed. Lemon and mint leaves are thoroughly washed under 
running water. The ginger was weighed after drying to be $14 \mathrm{~g} \pm 0.5 \mathrm{~g}$. Lemons are cut into $14 \mathrm{~g} \pm 0.5 \mathrm{~g}$ pieces and weighed. Mint leaves are weighed at $1 \mathrm{~g} \pm 0.5$ grams. The sample is then placed in a glass bottle, and $200 \mathrm{ml}$ of mineral water at a temperature of $37-40^{\circ} \mathrm{C}$ is added. Allow standing for 5 minutes before placing in the refrigerator for 6, 9, or 12 hours.

Next step was examination antioxidant activity by DPPH method using UV-Vis spectrometry, vitamin $\mathrm{C}$ levels using UV-Vis spectrometry and the degreeof acidity $(\mathrm{pH})$ using a $\mathrm{pH}$ meter.

\section{Results and discussion}

\subsection{Result}

\subsubsection{Antioxidant activity by DPPH method}

The DPPH method was used to test the antioxidant activity. A UV-Vis spectrophotometer was used to make the measurements. The maximum wavelength of DPPH was determined at $400-800 \mathrm{~nm}$ wavelengths until the maximum wavelength of $516 \mathrm{~nm}$ with a maximum absorbance of 0.758 was obtained. Furthermore, antioxidant activity was measured using the DPPH radical reduction method at the maximum wavelength.

Based on the research, the antioxidant activity of infused water was calculated by calculating the percentage of inhibition ( percent inhibition) of DPPH, yielding the following data (Figure 1):

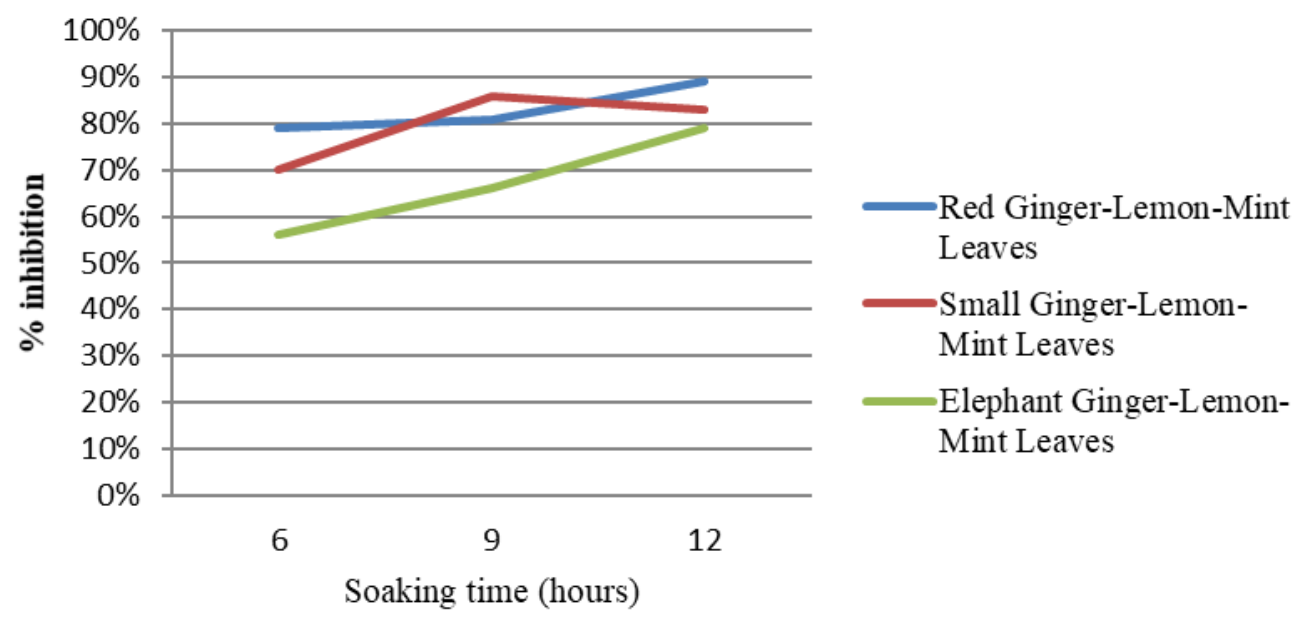

Fig. 1. Antioxidant activity of infused water

According to the data above, red ginger-infused water with lemon and mint leaves with soaking times of 6 hours, 9 hours, and 12 hours had the highest percentage of inhibition with 89 percent at 12 hours of immersion. While the infused water of small ginger with lemon and mint leaves with soaking times of 6 hours, 9 hours, and 12 hours had the highest percentage of inhibition with a value of 86 percent obtained at 9 hours of immersion. Elephant ginger-infused water with lemon and mint leaves with prolonged soaking times of 6 hours, 9 hours, and 12 hours had the highest percentage of inhibition with a value of 79 percent at 12 hours of immersion. 


\subsubsection{Vitamin C levels with UV-Vis spectrometry}

UV-Vis spectrometry was used to determine Vitamin C levels in infused water, with ascorbic acid serving as a control compound. Maximum wavelength determination Ascorbate was tested at 200-400 nm wavelengths until the maximum wavelength of $265 \mathrm{~nm}$ with a maximum absorbance of 0.471 was obtained. The standard curve for vitamin $C$ was then established. The standard solution curve results are used to calculate the linear regression equation $\mathrm{y}=\mathrm{ax}+\mathrm{b}$. The linear regression equation $\mathrm{y}=0.07807 \mathrm{x}+0.01844$ is obtained, with a correlation coefficient (r) of 0.9956. The vitamin $\mathrm{C}$ content of the sample is determined by measuring the absorbance of each sample (Figure 2).

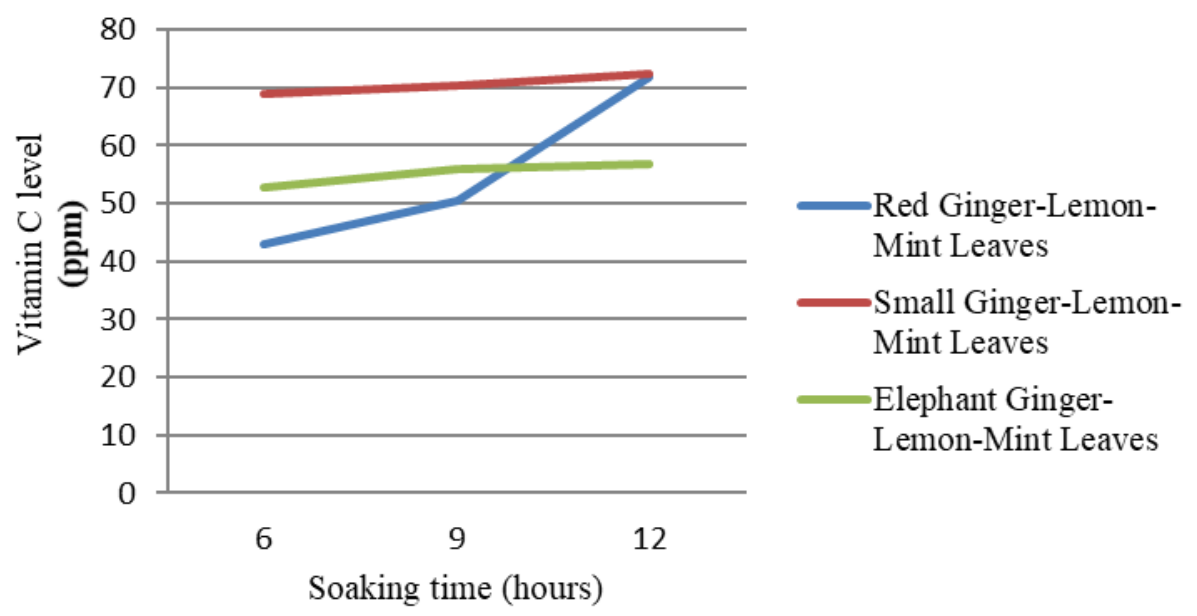

Fig. 2. Vitamin C infused water levels

According to the data above, red ginger-infused water with lemon and mint leaves with soaking 6 hours, 9 hours, and 12 hours had the highest vitamin C content, 71.72 ppm, at 12 hours immersion. While the infused water of small ginger with lemon and mint leaves with soaking times of 6 hours, 9 hours, and 12 hours had the highest levels of vitamin C (72.44 ppm) obtained at 12 hours immersion. The highest levels of vitamin $\mathrm{C}$ were obtained after 12 hours of immersion in elephant ginger-infused water with lemon and mint leaves, with soaking times of 6 hours, 9 hours, and 12 hours.

\subsubsection{Degree of acidity $(\mathrm{pH})$}

The level of acidity in infused water is determined by determining the $\mathrm{pH}$ value with a $\mathrm{pH}$ meter. The following $\mathrm{pH}$ values were obtained as a result of the research (Figure 3): 


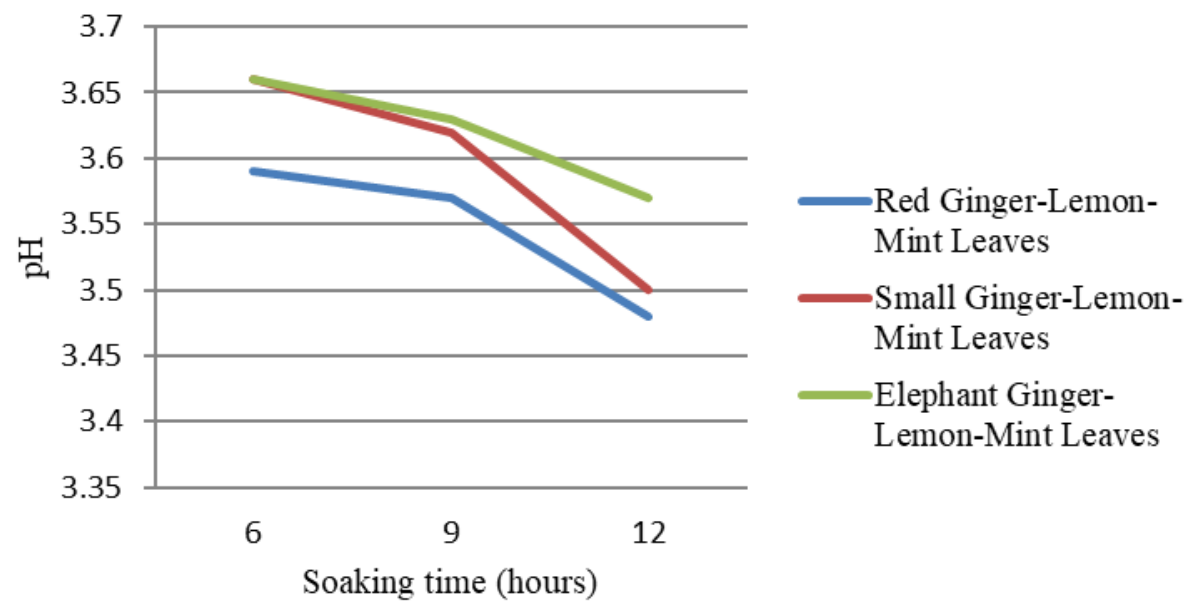

Fig. 3. $\mathrm{pH}$ value of infused water

According to the data above, the infused water of red ginger with lemon and mint leaves with soaking 6 hours, 9 hours, and 12 hours has the lowest $\mathrm{pH}$ value obtained at 12 hours of immersion, which is 3.48 the data above. While the infused water of small ginger with lemon and mint leaves with soaking times of 6 hours, 9 hours, and 12 hours yielded the lowest $\mathrm{pH}$ value, 3.5 , after 12 hours of immersion. Elephant ginger-infused water with lemon and mint leaves for 6 hours, 9 hours, and 12 hours of immersion had the lowest $\mathrm{pH}$ value, 3.57 , at 12 hours of immersion.

\subsection{Discussion}

Infused water is drinking water that has been infused with pieces of fruit, vegetables, or spices to allow the juices to come out and provide flavor and various health benefits to those who drink it [1]. The primary nutritional content of infused water is vitamins, minerals, and fiber. Infused water, also known as spa water, is water that has been mixed with fruit and then allowed to stand or ferment for several hours so that the juices that are beneficial to the body's health can diffuse into the water. The extracts from the fruit or spices used can flow into the water during the soaking process, providing freshness to the body and good health benefits. Some of the advantages of infused water include losing weight, making it easier to consume spices or fruit, and increasing antioxidant levels in the body [2].

Ginger is a spice plant commonly used as medicine by people in everyday life, as infused water. Processing ginger in infused water is becoming popular in society due to processing and extracting the ginger's content. Ginger is classified into three types based on the rhizome's size, shape, and color: red ginger, emprit ginger, and elephant ginger. Red ginger is the most minor, ranging from red to orange, with a strong aroma and coarse fibers. Small (emprit) ginger is medium-sized ginger that is white or yellow, slightly flattened, fibrous, and not too sharp. While elephant ginger has the largest rhizome size, it is yellow or light yellow, slightly fibrous and soft, and has a mild aroma.

In this study, ginger-infused water was made in three ways: red ginger, elephant ginger, and elephant ginger with lemon and mint leave. It is done based on people's habits when it comes to drinking infused water. Immersion times of 6 hours, 9 hours, and 12 hours are used to make infused water. 


\subsubsection{Antioxidant activity of infused water}

Antioxidants are substances that can protect the body from the formation of free radicals. Atoms or molecules with an unpaired electron in their orbital are classified as free radicals [10], [11]. To achieve chemical stability, free radicals cannot maintain their original shape for an extended period and immediately bind to the surrounding material. Free radicals will attack and steal electrons from the nearest stable molecule. Substances that absorb electrons will also become free radicals, causing a chain reaction that will eventually damage the cell [12]. Free radicals are found in the body as a result of the oxidation process and cell burning that occurs during breathing, cell metabolism, excessive or maximal exercise or physical activity, inflammation, and exposure to pollution from outside the body such as vehicle fumes, cigarette smoke, food, heavy metals, industry, and solar radiation.

Measurement of antioxidant activity in this study was carried out using the DPPH method. This method was chosen because it is simpler, faster, and more accurate than other methods. Antioxidant activity was measured based on the inhibition ( percent inhibition) of the sample against DPPH compounds. The research discovered that the red ginger sample with 12 hours of soaking had the highest inhibition (percent inhibition) against DPPH, with a percentage of 89 percent. The color change of the purple DPPH, which turns yellow when reacted with the sample, is evidenced by UV-Vis spectrometry. These results align with Wahyuningsih et al. [8], where red ginger had higher antioxidant activity than elephant ginger and small (emprit) ginger, with an inhibition percentage of 88.26 percent. Likewise, Pebiningrum \& Kusnadi [13], the antioxidant activity of red ginger in red ginger kombucha extract was 75.61 percent, which was higher than that of small (emprit) ginger and elephant ginger. The number of dissolved compounds in the water is also affected by soaking time. Ginger that has been soaked for 12 hours has higher antioxidant activity than ginger that has been soaked for 6 or 9 hours.

In vitro and in vivo, ginger contains bioactive compounds capable of scavenging free radicals [14]. Ginger's antioxidant activity can also be seen in its ability to protect DNA [15]. Non-volatile phenolic active compounds found in ginger, such as gingerol and shogaol, have been shown to have antioxidant properties, with gingerol and shagaol acting as primary antioxidants against lipid radicals [13]. Based on Hernani and Hayani[16], red ginger has more volatile oil (3.9 percent) and alcohol-soluble extract (9.93 percent) than small (emprit) ginger (3.5 percent and 7.29 percent) and elephant ginger (2.5 percent and 5.81 percent). The essential oil content and solubility determine the number of antioxidants and total phenols found in ginger. Ginger's bioactive components include (6)-gingerol, (6)shogaol, diarylheptanoid, and curcumin, which has antioxidant activity that exceeds that of tocopherol [17]. One of these ingredients helps to boost the antioxidant activity of the infused water.

\subsubsection{Vitamin C content}

Vitamins are organic compounds that the human body requires in small amounts to maintain life and health. Vitamins are classified into two types: water-soluble vitamins and fat-soluble vitamins (1). Water-soluble vitamins pass through the kidneys and are not stored in the body. Water-soluble vitamins are excreted in the urine and are not stored in the body. As a result, water-soluble vitamins must be consumed daily to avoid deficiencies that can interfere with normal body functions. Vitamin C (ascorbic acid) is a water-soluble vitamin that serves an essential function in the body as a coenzyme or cofactor [18].

The levels of vitamin $C$ infused water was measured using UV-Vis spectrometry in this study, with ascorbic acid serving as a control compound. To measure vitamin C levels, a standard solution curve of ascorbic acid was first created. Later, the ascorbic acid 
regression equation was used to calculate vitamin $\mathrm{C}$ levels in infused water. With a correlation coefficient ( $\mathrm{r}$ ) of 0.9956 , the linear regression equation $\mathrm{y}=0.07807 \mathrm{x}+0.01844$. Acceptance criteria and a correlation coefficient (r) of $r>0.99$ indicate excellent linearity, which means that the absorbance value increases due to the curve between absorbance and concentration.

According to the research, ginger-infused water with a soaking time of 12 hours had the highest levels of vitamin $C$ infused water at $72.44 \mathrm{ppm}$. Infused water is a beverage made from the diffusion of plant materials extracted from spices or fruit into the water solvent used. Vitamin $\mathrm{C}$ also serves as an antioxidant in the body, increasing metabolic processes that generate energy. Ginger contains vitamin C $12 \mathrm{mg} / 100 \mathrm{gr}$ [4] and lemon contains vitamin C 60-100 mg/100 g [19], and mint leaves $51.47 \mathrm{mg} / 100 \mathrm{~g}$ [20].

\subsubsection{Degree of acidity $(\mathrm{pH})$}

A pH meter can be used to measure the level of acid or base. The $\mathrm{pH}$ value plays a vital role in daily life and must be monitored for quality control of pharmaceutical, cosmetic, and food products [21]. The acidity of the infused water was measured using a $\mathrm{pH}$ meter in this study. According to the study results, the $\mathrm{pH}$ value of 3.5 was obtained in infused water of small (emprit) ginger.

According to Ibrahim et al. [22], folic acid and pantothenic acid are found in ginger. Furthermore, organic acids such as malic acid or apple acid, and oxalic acid are found in ginger. Citric acid, an organic acid found in lemons, occurs naturally in the fruit. The degree of acidity $(\mathrm{pH})$ produced tends to decrease as immersion time increases. It is most likely due to the increased dissolution of chemical components in acidic materials. The $\mathrm{pH}$ value is related to vitamin $\mathrm{C}$ levels. The $\mathrm{pH}$ of foods with high levels of vitamin $\mathrm{C}$ tends to decrease. One of the ingredients in this study's infused water is lemon. Because lemons are high in vitamin $\mathrm{C}$, the $\mathrm{pH}$ of the infused water decreases with prolonged soaking.

\section{Conclusion}

Results from the study can be concluded that red ginger-infused water with a soaking time of 12 hours had the highest antioxidant activity and the elephant ginger had the lowest antioxidant activity after soaking for 6 hours. The highest levels of vitamin $\mathrm{C}$ infused water were found in small (emprit) ginger after soaking for 12 hours, and the lowest levels of vitamin $\mathrm{C}$ were found in elephant ginger after soaking for 6 hours. The lowest degree of acidity $(\mathrm{pH})$ was found in small (emprit) ginger after soaking for 12 hours, and the highest in elephant ginger after soaking for 6 hours.

\section{References}

1. N. Soraya, Infused Water: Minuman Alami Bervitamin dan Super Sehat (Penebar Plus, Bogor, 2014)

2. Y. Marzuqi, Infused Water (Buana Ilmu Populer, Jakarta, 2014)

3. C. J. Etheridge and E. Derbyshire, Nutr. Food Sci., 50, 969-985 (2020)

4. Budhawaar, Khasiat Rahsia Jahe dan Kunyit (Buana Ilmu Populer, Jakarta, 2006)

5. C. E. Tamer, F. Z. Yekeler, Ö. U. Çopur, B. İncedayi, and S. Suna, Food Sci. Technol, Campinas, 37, 45-51 (2017)

6. USDA, "USDA Food Composition Database.," (2016)

7. A. Gizi, Tabel Komposisi Pangan Indonesia (Kompas Gramedia, Jakarta, 2009)

8. A. M. Nur Wahyuningsih, N. Suhartatik, 1, 89-99 (2018) 
9. Harifah, J. Teknol. Dan Ind. Pangan, 1, 54-58 (2017)

10. H. Clarkson, P. M. dan Thompson, Am J Clin Nutr, 72 (2000)

11. J. Silalahi, Makanan Fungsional (Kanisius, Yogyakarta, 2006)

12. W. Drooge, Free radicals in the physiological control of cell function. (2002)

13. A. Pebiningrum and J. Kusnadi, 1, 33-42 (2018)

14. Y. M. T. Tientcheu et al., EJMP, 32, 22-33 (2021)

15. C. Imo and J. Salvation, Curr. Trensd Biomed. Eng. Biosci., 18 (2019)

16. H. \& Hayani, "Identification of chemical components on red ginger (Zingiber officinale var. Rubrum) by GC-MS," in Proceding seminars: natural products chemistry and utilization of natural resources (2001)

17. H. Kikuzaki and N. Nakatani, J.Food Sci, 58, 1487 (1993)

18. A. P. Dewi, JOPS, 2, 9-13, (2019)

19. M. R. . Perles, Moreno, and C. Viguera, "Natural Bioactive Compounds of Citrus Limon for Food and Health," J. Pharm. Biomed. Anal., (2010)

20. K. B. Santi, "Pengaruh Lama Pengeringan Dan Perbandingan Daun Kenikir (Cosmos Caudatus) Dan Daun Mint (Mentha Piperita, L.) Terhadap Karakteristik Teh Celup Herbal Campuran," (2018)

21. H. Wasito, E. Karyati, C. D. Vikarosa, I. N. Hafizah, and H. R. Utami, Indones. J. Chem. Sci., 6, 223-229 (2017)

22. I. A.M, Yunianta, and Sriherfyna, J. Pangan dan Agroindustri UB, 3, 1-12 (2015) 